Biochem. Lett, Vol. 6, PP. $45-68$ (2010)

\title{
IN VIVO AND IN VITRO EXPRESSIONS OF CCR1 AND CCR5 IN PATIENTS WITH ACTIVE SCHISTOSOMIASIS AND CHRONIC LIVER DISEASE
}

\author{
Samir A. El-Masry ${ }^{1}$; Mona S. Gouida ${ }^{2}$; Khalid M. \\ El-azab ${ }^{3}$ and Mahmoud E Nasr'. \\ ${ }^{1}$ Molecular Biology Department, Genetic Engineering and \\ Biotechnology Research Institute, Menufyia University, \\ Sadat City, Egypt. \\ ${ }^{2}$ Flow Cytometry and Genetic Units, Mansoura Children \\ Hospital, Mansoura University, Egypt. \\ ${ }^{3}$ Medical Analysis Specialist, Egypt.
}

\begin{abstract}
The CCL3 receptors, CCR1 and CCR5, are expressed in a series of cell types. The aim of the present study was to demonstrate, in vitro and in vivo, expressions of CCR1 and CCR5 on peripheral blood mononuclear cells (PBMCs) from healthy individuals and Schistosoma mansoni (S. mansoni) infected patients with chronic liver diseases (CLD).

PBMCs were isolated from the blood of 55 individuals divided into four groups; Group I: thirty one patients with CLD; group II: six patients with active $S$. mansoni infection, diagnosed by parasitological examination; group III: eight healthy individuals, non-infected with both schistosomiasis or viral infections, followed by treatment with soluble $S$. mansoni eggs antigens (SEA) after short term cells culture, for in vitro studies and group IV: ten healthy individuals, non-infected with both schistosomiasis or viral infections and served as a negative control group. All PBMCs from the studied groups were stained with monoclonal antibodies against CD4, CD8, CCR1 and CCR5, then detected by a flow cytometry technique.
\end{abstract}


In-vitro study revealed that CCR1 and CCR5 expressions in SEA treated short term culture of PBMCs were not significantly lower than healthy controls $(P=0.56$ and 0.298 , respectively). Also, In-vivo study, in active schistosomiasis patients, the decrement were not significant $(P=0.313$ and 0.093 , respectively) compared with a healthy control group. While in CLD patients there was an increment in expression of CCR1 with significant value $(p=0.014)$, as well as in CCR5 but the increment were not significant $(P=0.099)$. Patients with active schistosomiasis showed lower CD4 and higher CD8 T-cells count compared with healthy controls. The expressions of CD4 and CD8 T-cells were not significant $(P=0.368$, 0.875 , respectively).

CCR1 and CCR5 expressions may play a role in recruitment of lymphocytes to the CLD patients. CD4 was down regulated and CD8 $T$ cells were up regulated in PBMCs of active schistosomiasis patients.

KEYWORDS: CCR1 - CCR5 - Schistosoma mansoni chronic liver diseases - active schistosomiasis - HCV - SEA chemokine receptors.

Corresponding Auther: Dr/ Samir Ali Mohamed El-Masry, Email address: samirelmasry@yahoo.com

\section{INTRODUCTION}

Schistosomiasis is a parasitic disease caused by platyhelminth worms of the genus Schistosoma affecting 207 millions people in the developing world, the children mostly, at risk of the infection. No effective vaccine is available as yet to eradicate the disease via elimination of transmission ${ }^{(1,2,3)}$.

Schistosome infection presents a complex challenge to the immune system. The parasite is a multicellular organism which exists in discrete life stages and inhabits multiple locations within the host. The infected persons with $S$. mansoni may develop to 


\section{Expression of CCR1 \& CCR5 in shistosomiasts patients}

hepatosplenomegaly, portal hypertension and upper gastrointestinal bleeding, haemorrhage, and death ${ }^{(4,5,6,7)}$.

Previous studies in the murine model have demonstrated that granuloma formation was induced by soluble egg antigens (SEA) released from schistosomal eggs and granulomatous inflammation was dependent on the activation of $\mathrm{CD}^{+} \mathrm{T}$ helper lymphocytes ${ }^{(\mathbf{8 , 9})}$.

Some studies have focused on the role of chemokines in schistosomiasis. Data obtained from murine models suggested that chemokines dictate the type and intensity of inflammatory infiltrate during the granulomatous response against egg antigens ${ }^{(10)}$.

The CCL3 chemokine seemed to be particularly relevant in schistosomiasis. This assumption was reinforced by studies involving human subjects. Patients with $S$. mansoni had elevated plasma concentrations of CCL3, CCL5 and CCL11. In vitro studies demonstrated that PBMCs from infected patients produced high levels of CCL3 when exposed to egg antigen-coupled beads ${ }^{(11,12)}$.

The CCL3 receptors, CCR1 and CCR5, are expressed in a series of cell types, including neutrophils, monocytes, macrophages, $\mathrm{T}$ and $\mathrm{B}$ lymphocytes, eosinophils, dendritic cells (DC), natural killer (NK) cells, thymocytes, platelets, endothelial, and striated cardiac muscle cells ${ }^{(\mathbf{1 3})}$. CCR5 act as a receptor for CCL5, this action may preferentially recruit regulatory cells ${ }^{(14,15)}$. Also, CCL5 had a role of in experimental $S$. mansoni infection. In this regard, CCL5 action on CCR5 would favor a regulated response and milder forms of the disease. Indeed, one study has demonstrated a higher risk of fibrosis of schistosomiasis patients whose peripheral blood cells respond to SEA stimulation by producing intermediate levels of tumor necrosis factor- $\alpha(\mathrm{TNF}-\alpha)$ associated with low CCL5, indicating a protective role of CCL5. On the other hand, severe forms of disease would result from unbalanced chemokine receptor activation towards an increased activation of CCR1 predominantly mediated by CCL3 $(16,17,11,18,12,19)$.

In the present study, we aimed to evaluate the role of SEA in the interaction with the immune system with special reference to CCR1 and CCR5 chemokines receptor in vivo expression in patients 
with active schistosomiasis and chronic liver diseases. As well as in vitro expression in short term culture of PBMCs treated with SEA.

\section{MATERIALS AND METHODS}

\section{Study Population:}

Blood samples were obtained from fifty five individuals, divided into four groups: Group I; included thirty one patients with chronic liver diseases, 10 males and 21 females with age ranged from 37 to 65 y $(52.42 \pm 6.95$ y). Group II; included six patients infected with $S$. mansoni, 3 males and 3 females, with age ranged from 31 to $63 \mathrm{y}(40.17 \pm 11.53 \mathrm{y})$, diagnosed by parasitological examination, Group III; included eight healthy individuals 5 males and 3 females with age ranged from 26 to $41 \mathrm{y}(33.13 \pm 4.97 \mathrm{y})$, followed by treatment with SEA of $S$. mansoni after short term culture, for in vitro studies and Group IV; included ten healthy individuals, 6 males and 4 females with age ranged from 25 to $42 \mathrm{y}(32.7 \pm 5.5 \mathrm{y})$ and served as a negative control (Table 1). These samples were taken between December 2008 to August 2009. Patients with liver diseases were routinely investigated after hospitalization in Tropical Medicine Unit, Mansoura University Hospital, Egypt. Healthy control samples were obtained from Mansoura University Pediatric Hospital Blood Bank.

All patients included in this study had the procedure thoroughly explained to them. The clinical/biochemical datas of the patients were recorded, including age, sex, platelets count, viral infections, Hepatitis C Virus (HCV) and Hepatitis B Virus (HBV), biochemical liver function test results, and anti-bilharzial antibodies by indirect haemagglutination test (IHA). 
Expression of CCR1 \& CCR5 in shistosomiasts patients

Table (1) Descriptive data about age and sex of different groups:

\begin{tabular}{|l|c|c|c|}
\hline \multirow{2}{*}{ Studied groups } & Age/ year & \multicolumn{2}{c|}{ Sex } \\
\cline { 2 - 4 } & Mean \pm SD & Males & Females \\
\hline $\begin{array}{l}\text { I (Chronic liver } \\
\text { diseases) } \mathrm{n}=31\end{array}$ & $52.42 \pm 6.95$ & $10(32.3 \%)$ & $21(67.7 \%)$ \\
\hline $\begin{array}{c}\text { II (Active } \\
\text { schistosomiasis) } \mathrm{n}=6\end{array}$ & $40.17 \pm 11.53$ & $3(50 \%)$ & $3(50 \%)$ \\
\hline $\begin{array}{c}\text { III (PBMCs treated } \\
\text { with SEA) } \mathrm{n}=8\end{array}$ & $33.13 \pm 4.97$ & $5(62.5 \%)$ & $3(37.5 \%)$ \\
\hline $\begin{array}{c}\text { IV (Healthy control) } \\
\mathrm{n}=10\end{array}$ & $32.70 \pm 5.50$ & $6(60 \%)$ & $4(40 \%)$ \\
\hline
\end{tabular}

\section{Isolation of Peripheral Blood Mononuclear Cells (PBMCs):}

Five milliliters of venous blood were collected from all subjects on EDTA vacationer tube. PBMCs were separated by layering of the diluted blood, with five milliliters PBS and $10 \%$ fetal calf serum (FCS), over Lympho-flot (Sodium diatrizoate $11.00 \%$ and Ficoll $6.35 \%$ ) density gradient (Biotest Germany) for the isolation of lymphocytes ${ }^{(20,21)}$, followed by centrifugation at $1500 \mathrm{rpm}$ for 20 min. Lymphocytes were isolated and washed with Hanks solution. After centrifugation for $10 \mathrm{~min}$ at $1500 \mathrm{rpm}$, the supernatant was decanted and the lymphocytes were fixed with ice absolute ethanol (22).

\section{Monoclonal and polyclonal antibodies}

FITC-labeled monoclonal antibodies (mAbs) against CD4 (MHCD0401-4; in vitro diagnostic use, Caltag laboratories) and CD8 (MHCD0801-4; in vitro diagnostic use, Caltag laboratories) were used in this study. Unconjugated mAbs antibodies against CCR1 (rabbit polyclonal, ab 1681) and CCR5 (goat polyclonal, ab 1673) (R\&D Systems, abcam U.K.) were used as primary antibodies for detection of chemokine receptors on PMNCs. FITC IgG polyclonal 
swine anti-rabbit (Nr. F 0054; in vitro diagnostic use, Dako Cytomation Denmark) and FITC IgG polyclonal donkey anti-goat (ab 6881 H\& L Systems, abcam U. K.) were used as secondary antibodies.

\section{Short-term peripheral blood lymphocytes culture:}

White blood cell counts: Hemograms were performed using an automated hematological electronic counter (Coulter MD18, E.U.A) using whole blood collected in $5 \mathrm{ml}$ vacutainer tubes containing EDTA as anticoagulant. The parameters measured included global white blood cell counts and differential analysis of leukocytes subpopulations including the absolute counts of granulocytes (neutrophils and eosinophils), lymphocytes and monocytes.

S. mansoni antigen: Soluble antigenic preparation was obtained from SEA, (schistosome Biological Supply Center, Theodor Bilharz Research Institute, Cairo, Egypt). This antigen was added based on its protein content to give maximum responsiveness with most patients $(25 \mu \mathrm{g} / \mathrm{ml})$.

Cell preparations: Human PBMCs were isolated from heparinzed blood by layering diluted blood as mentioned above (under sterilizing condition). Short-term cultures were performed in the presence of SEA. Adherent and non adherent cell populations were obtained from PBMC $2.0 \times 10^{6} / \mathrm{ml}$ using tissue culture plates(TPP Tissue Culture and Laboratory technology, AG, Switzerland) with culture medium RPMI 1640 containing 1.6\% Lglutamine, $300 \mathrm{U} / \mathrm{ml}$ of penicillin, $0.3 \mathrm{mg} / \mathrm{ml}$ of streptomycin and $10 \%$ heat-inactivated Fetal Bovine Serum (Biowest, S $1810-100$ South America). The viability was greater than $90 \%$ as measured by trypan blue exclusion test. 


\section{Expression of CCR1 \& CCR5 in shistosomiasts patients}

Proliferation assay: Briefly, $2.0 \times 10^{6}$ lymphocytes/well were co-cultured with SEA $(5 \mu \mathrm{g} /$ well $)$, adherent cells in different stages of differentiation (maintained in culture for $0,2,4$ or 6 days) in a total volume of $250 \mu \mathrm{l}$, using a flat bottom 24 well plate at $37^{\circ} \mathrm{C}$ and $5 \% \mathrm{CO}_{2} / 95 \%$ in an air humidified incubator. These conditions were chosen considering that the detection of cytokines, particularly in the absence of exogenous stimuli, may reflect the events of cytokine production by blood leukocytes in vivo.

\section{Staining method}

PMNCs were suspended in phosphate buffered saline (PBS), pH 7.4 containing $0.05 \%$ bovine serum albumin (BSA), followed by centrifugation at $1500 \mathrm{rpm}$ for $5 \mathrm{~min}$. The supernatants were decanted, and then parts of cells were incubated at room temperature (R.T.) with $5 \mu \mathrm{l}$ of CD4 and $5 \mu \mathrm{l}$ of CD8 mAbs for 20 min in two tubes separately. Also, other parts of cells were incubated at R.T. with $10 \mu \mathrm{l}$ of CCR1 and $10 \mu \mathrm{l}$ of CCR5 mAbs for $40 \mathrm{~min}$ in another two tubes separately, followed by incubation with $5 \mu$ IITCconjugated polyclonal secondary antibodies at R.T. for $10 \mathrm{~min}$. Finally, the cells in four tubes were washed with PBS, BSA buffer and fixed with $1 \%$ paraformaldehyde solution. 20,000 cells were analyzed by flow cytometry on a FACCalibur flow cytometer using Cellquest software. Also, we use the FITC IgG polyclonal swine antirabbit as a secondary isotype to stain the cells (direct stain like CD4 and CD8) for the calibration of the instrument and as a guide for FITC intensity fluorescence.

\section{DNA Ploidy Analysis:}

Cells isolated on Lymphoflot were fixed in ice-cold $99 \%$ ethanol and stained with a saturating concentration $(50 \mu \mathrm{g} / \mathrm{mL})$ of propidium iodide and $100 \mu \mathrm{g} / \mathrm{mL}$ of RNase. Sample were stained and processed after staining, the samples were protected from light and analyzed within 2 hours.

Flow cytometric ploidy analysis was performed with a FACS calibur flow cytometer using Cell quest software (Becton Dickinson). For each sample, 10,000 cells were analyzed. Single cells were 
discriminated from cell clumps by a doublet discrimination model (pulse area vs. pulse width). The DNA histograms were evaluated using the MODFIT mode. ${ }^{(23)}$.

The flow DNA histograms were classified morphologically into diploid and aneuploid patterns ${ }^{(24)}$. An aneuploid cell population was considered to be present if a distinct peak, in addition to the G1 diploid peak, was found in position deviating more than $10 \%$ from the diploid internal standard or if the G1 itself was deviating more than $10 \%$. The degree of diploid of this aneuploid cell population was calculated by relating the G1 maximum of these cells to the DNA content of diploid G1 cells that usually were present. A corresponding G2+M peak existed at double the DNA content of the G1 aneuploid peak. Therefore, to identify peaks in the tetraploid region of the histogram as a tetraploid tumor stem line, the proportion of cells in this peak must clearly be greater than that of normal human lymph node cells and normal lymphocyte ${ }^{(25)}$. Apoptosis will be measure by using the sub G1 peak staining with propidium Iodide ${ }^{(26)}$.

\section{Statistical analysis:-}

Statistical package (SPSS, version 17.0) was used for data management. Descriptive statistics was presented as valid number, mean, standard deviations for continuous variables. Unpaired Student t-test (two sided) was used to test the significance of difference between the mean value of studied groups.

\section{RESULTS \\ In vitro expressions of CCR1 and CCR5}

In vitro studies, for the evaluation of the expressions of CCR 1 and CCR5 in short term culture of PBMCs isolated from the blood of twelve healthy individuals, eight samples were treated separately with S. mansoni SEA and four untreated samples, served as a negative control. The expression of both CCR 1 and CCR5 were detected by a flow cytometry technique as well as the parameters of cell cycle (G0/G1, S phase \%, G2/M, G2/G1 and Apoptosis) along six days of short term culture (from day zero to day six). 
The results revealed that there were a decrement in the expression of both CCR1 and CCR5 along the six days cultures in comparison with their decrement expressions in untreated samples. CCR1 levels in untreated samples were decreased from zero to 2nd, 4th and 6th days $(\mathrm{M} \pm \mathrm{SD}=29.82 \pm 3.15,18.26 \pm 9.33,18.02 \pm 8.93$, $16.80 \pm 9.93$, respectively). Also, it was decreased in treated samples from zero to $2 \mathrm{nd}$, 4 th and 6 th days $(\mathrm{M} \pm \mathrm{SD}=23.72 \pm 10.57,20.06 \pm 5.66$, $15.98 \pm 5.86$ and $16.89 \pm 4.70$, respectively) as shown in table (2) and figure $(1,4)$. Statistically, no significant difference in correlation between untreated and treated samples $(\mathrm{P}>0.05)$.
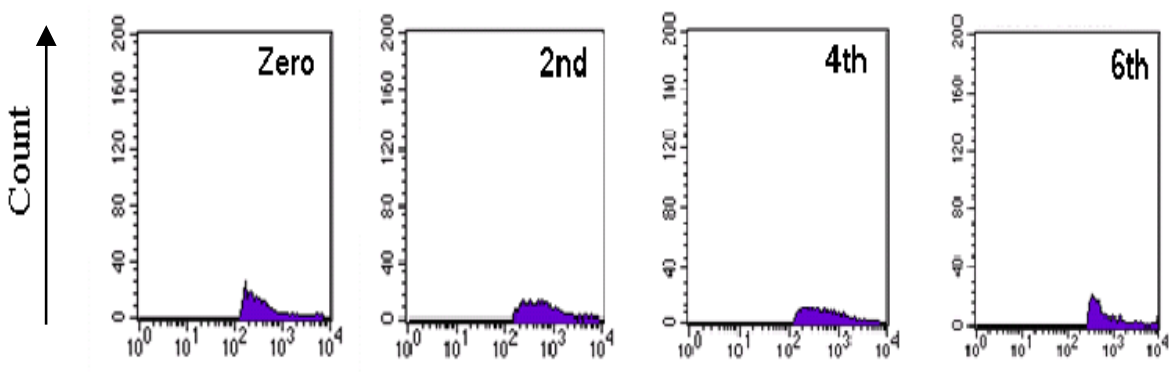

Intensity of fluorescence (CCR1 FITC)

Figure 1: show positive gated cells in treated group with SEA in zero, 2nd, 4th, 6th days. Histogram plot of fluorescence Intensity for CCR1FITC.

CCR5 levels in untreated samples were gradually decreased from zero to $2^{\text {nd }}, 4^{\text {th }}$ and $6^{\text {th }}$ days $(\mathrm{M} \pm \mathrm{SD}=30.89 \pm 4.89,23.78 \pm 15.19$, $8.13 \pm 4.24$ and $6.86 \pm 4.17$, respectively) and also its levels were decreased in treated samples from zero to $2^{\text {nd }}, 4^{\text {th }}$ and $6^{\text {th }}$ days $(\mathrm{M} \pm \mathrm{SD}=23.78 \pm 15.19, \quad 14.90 \pm 4.56, \quad 14.21 \pm 6.81$ and 9.33 \pm 5.40 , respectively) as shown in table (2) and figure (2, 4). Statistically, no significant difference in correlation between untreated and treated samples $(\mathrm{P}>0.05)$. 

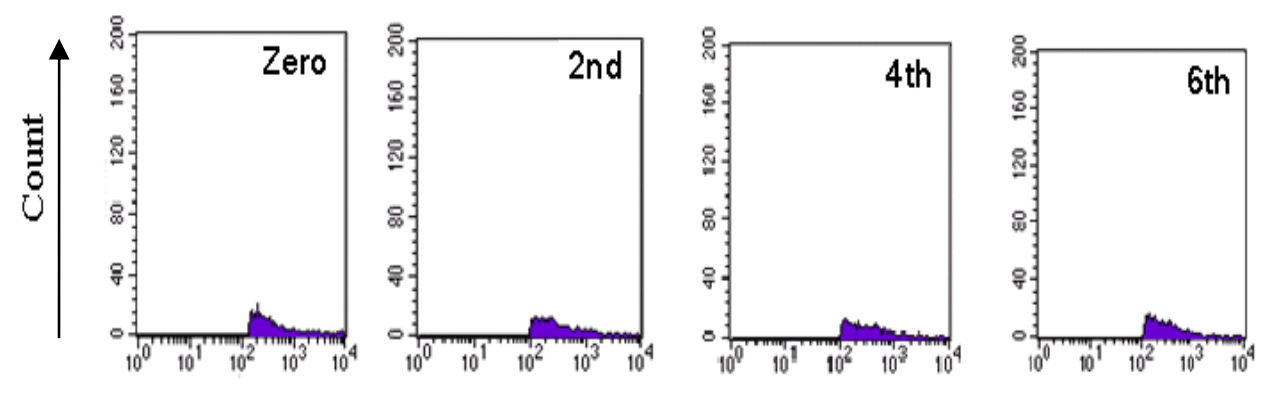

Intensity of fluorescence (CCR5 FITC)

Figure 2: show positive gated cells in treated group with SEA in zero, 2nd, 4th, 6th days. Histogram plot of fluorescence Intensity for CCR5FITC.

Regarding to the parameters of cell cycle, the results revealed that, in untreated samples, we found that $S$ phase values have gradually decrease from zero to $2^{\text {nd }}, 4^{\text {th }}$ and $6^{\text {th }}$ day $(\mathrm{M} \pm \mathrm{SD}=$ $6.56 \pm 2.41,4.92 \pm 8.01,2.64 \pm 3.82$ and $2.83 \pm 3.71$, respectively) as shown in table (2) and figure $(3,4)$, while in treated samples, we found that $\mathrm{S}$ phase values have marked decrease from zero to $2^{\text {nd }}, 4^{\text {th }}$ and $6^{\text {th }}$ days $(\mathrm{M} \pm \mathrm{SD}=12.03 \pm 10.28,1.24 \pm 2.64,1.16 \pm 2.31$ and $2.82 \pm 4.75$, respectively) as shown in table (2) and figure $(3,4)$. Statistically, no significant difference in correlation between untreated and treated samples $(\mathrm{P}>0.05)$

Apoptosis levels in untreated samples were increased from zero to $2^{\text {nd }}$ day then decreased again gradually in $4^{\text {th }}$ and $6^{\text {th }}$ day $(\mathrm{M} \pm \mathrm{SD}=19.47 \pm 23.20,32.17 \pm 8.68,19.28 \pm 22.76$ and $9.17 \pm 6.77$ respectively). While in treated samples, we found that there was a gradual increase in apoptosis from zero to $2^{\text {nd }}$ and $4^{\text {th }}$ days then marked decrease in $6^{\text {th }}$ day $(\mathrm{M} \pm \mathrm{SD}=5.68 \pm 9.81,23.90 \pm 18.59$, $38.08 \pm 22.41$ and $27.07 \pm 28.04$, respectively) as shown in table (2) and figure $(3,4)$. Statistically, no significant difference in correlation between untreated and treated samples $(\mathrm{P}>0.05)$. 


\section{In vivo expressions of CCR1 and CCR5}

In vivo expressions of CCR 1 and CCR 5 were evaluated by detection of their levels in PBMNCs isolated from thirty one patients with CLD (group I), six patients with active schistosomiasis (group II) and ten healthy control individuals (group IV). The expression of both CCR 1 and CCR 5 were detected by a flow cytometry technique as well as CD4 and CD8 T-cells in all groups.

The results showed that CCR1 levels were increased in group I $(\mathrm{M} \pm \mathrm{SD}=36.24 \pm 7.28)$ than that in group IV $(\mathrm{M} \pm \mathrm{SD}=29.49 \pm 6.33)$. Statistically, there was significant difference in correlation between group IV and group I $(\mathrm{P} \leq 0.05)$. Also, CCR5 levels were slightly increased in group $\mathrm{I}(\mathrm{M} \pm \mathrm{SD}=34.78 \pm 8.29)$ than that in group IV $(\mathrm{M} \pm \mathrm{SD}=30.52 \pm 5.23)$. Statistically, no significant difference in correlation between group IV and group I $(\mathrm{P}>0.05)$ as shown in table (3) and figure (5).

Also, CD4 and CD8 levels were significantly increased $((\mathrm{P} \leq 0.05))$ in group $\mathrm{I}(\mathrm{M} \pm \mathrm{SD}=35.22 \pm 16.96$ and 43.97 \pm 19.43 , respectively) than that in group IV $(\mathrm{M} \pm \mathrm{SD}=23.45 \pm 5.75$ and $26.47 \pm 8.70$, respectively) as shown in table (3) and figure (5). 

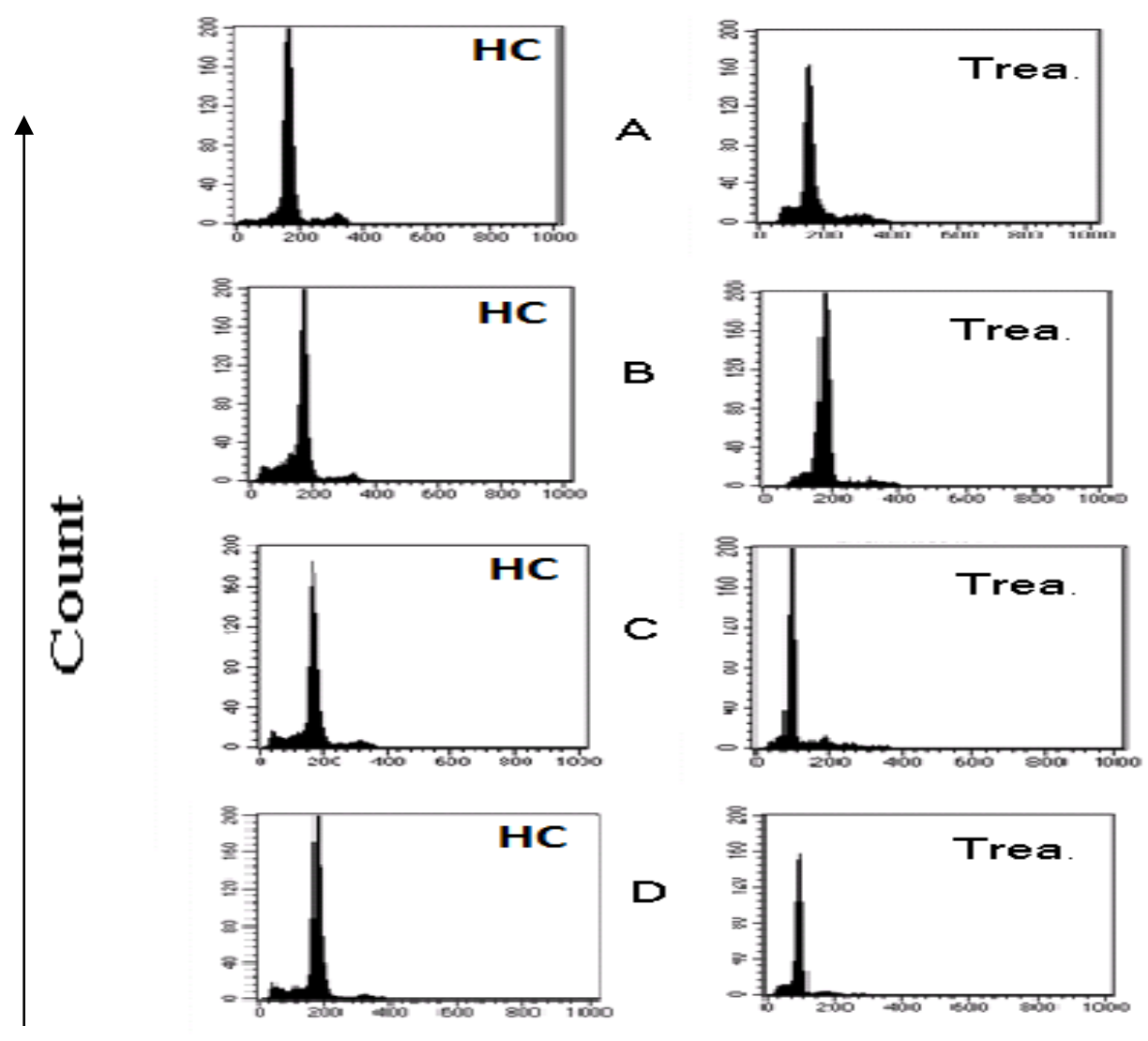

Intensity of fluorescence

Figure 3: positive gated cells within cell cycle in untreated control samples and treated samples with SEA. A: Zero day, B: $2^{\text {nd }}$ day, C: $4^{\text {th }}$ day, D: $6^{\text {th }}$ day of culture

Regarding to active schistosomiasis group, the results showed that there were a slightly decrement $(\mathrm{P}>0.05)$ in expressions of CCR1, CCR5 and CD4 $(\mathrm{M} \pm \mathrm{SD}=25.27 \pm 7.26,23.43 \pm 8.04$ and $19.96 \pm 6.39$ respectively) compared with their expressions in a healthy control group $(\mathrm{M} \pm \mathrm{SD}=29.49 \pm 6.33,30.52 \pm 5.23$ and $23.45 \pm 5.75$ respectively) as shown in table (4) and figure (6). On the other hand, there was a 
slightly increment $(\mathrm{P}>0.05)$ in the $\mathrm{CD} 8$ expression $(\mathrm{M} \pm \mathrm{SD}=$ $33.88 \pm 21.61)$ compared with a healthy control group $(\mathrm{M} \pm \mathrm{SD}=$ $26.47 \pm 8.70$ ) as shown in table (4) and figure (6).

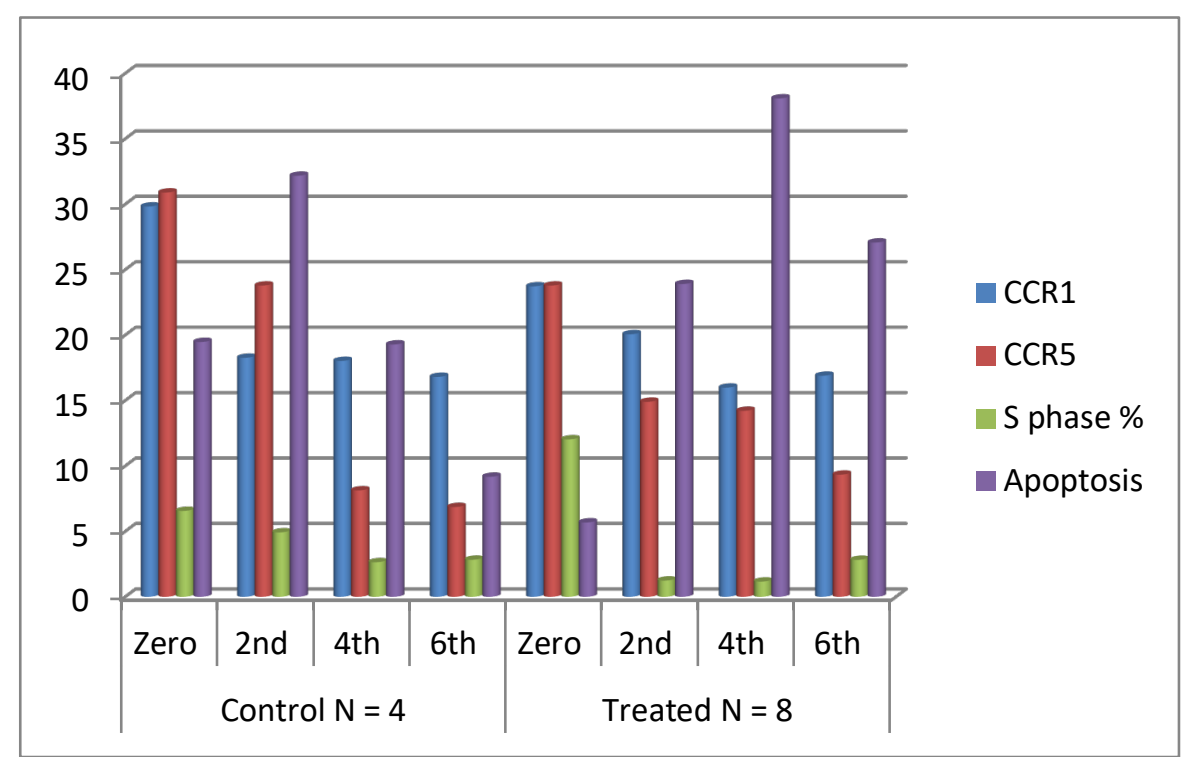

Figure 4: Levels of CCR1, CCR5, S phase and Apoptosis in treated and untreated samples.

\section{Correlation between expressions of CCR1 and CCR5 in vivo and in vitro:}

The correlation between the expression of both CCR1 and CCR5 in short term culture of SEA treated PBMNCs (in vitro) and their expressions in PBMNCs of active schistosomiais patients (in vivo), revealed that CCR1 level had no marked difference $(\mathrm{P}>0.05)$ between zero day in treated group and active schistosomiasis $(\mathrm{M} \pm \mathrm{SD}$ $=23.72 \pm 10.57$ and $25.27 \pm 7.26$, respectively) as shown in figure 4 . Also CCR5 level had no difference $(\mathrm{P}>0.05)$ between zero day in 
treated group and active schistosomiais group $(\mathrm{M} \pm \mathrm{SD}=23.78 \pm 15.19$ and $23.43 \pm 8.04$, respectively) as shown in figure (6) .

Table 3: CCR1, CCR5, CD4 and CD8 in control and CLD

\begin{tabular}{|c|c|c|c|c|}
\hline Studied groups & $\begin{array}{c}\text { CCR1 } \\
\text { Mean } \pm \text { SD }\end{array}$ & $\begin{array}{c}\text { CCR5 } \\
\text { Mean } \pm \text { SD }\end{array}$ & $\begin{array}{c}\text { CD4 } \\
\text { Mean } \pm \text { SD }\end{array}$ & $\begin{array}{c}\text { CD8 } \\
\text { Mean } \pm \text { SD }\end{array}$ \\
\hline $\begin{array}{c}\text { Control }(\mathrm{n}=10) \\
\text { CLD }\end{array}$ & $29.49 \pm 6.33$ & $30.52 \pm 5.23$ & $23.45 \pm 5.75$ & $26.47 \pm 8.70$ \\
\hline$(\mathrm{n}=31)$ & $36.24 \pm 7.28$ & $34.78 \pm 8.29$ & $35.22 \pm 16.96$ & $43.97 \pm 19.43$ \\
\hline P value & $0.014^{*}$ & 0.099 & $0.028^{*}$ & $0.011^{*}$ \\
\hline
\end{tabular}

* Significant comparing with healthy controls

Table 4: CCR1, CCR5, CD4 and CD8 in Control and active schistosomiais

\begin{tabular}{|c|c|c|c|c|}
\hline Studied groups & $\begin{array}{c}\text { CCR1 } \\
\text { Mean } \pm \text { SD }\end{array}$ & $\begin{array}{c}\text { CCR5 } \\
\text { Mean } \pm \text { SD }\end{array}$ & $\begin{array}{c}\text { Cd4 } \\
\text { Mean } \pm \text { SD }\end{array}$ & $\begin{array}{c}\text { Cd8 } \\
\text { Mean } \pm \text { SD }\end{array}$ \\
\hline Control $(\mathrm{n}=10)$ & $29.49 \pm 6.33$ & $30.52 \pm 5.23$ & $23.45 \pm 5.75$ & $26.47 \pm 8.70$ \\
\hline $\begin{array}{c}\text { Active } \\
\text { schistosomiais } \\
(\mathrm{n}=6)\end{array}$ & $25.27 \pm 7.26$ & $23.43 \pm 8.04$ & $19.96 \pm 6.39$ & $33.88 \pm 21.61$ \\
\hline P value & 0.313 & 0.093 & 0.368 & 0.875 \\
\hline
\end{tabular}




\section{Expression of CCR1 \& CCR5 in shistosomiasts patients}

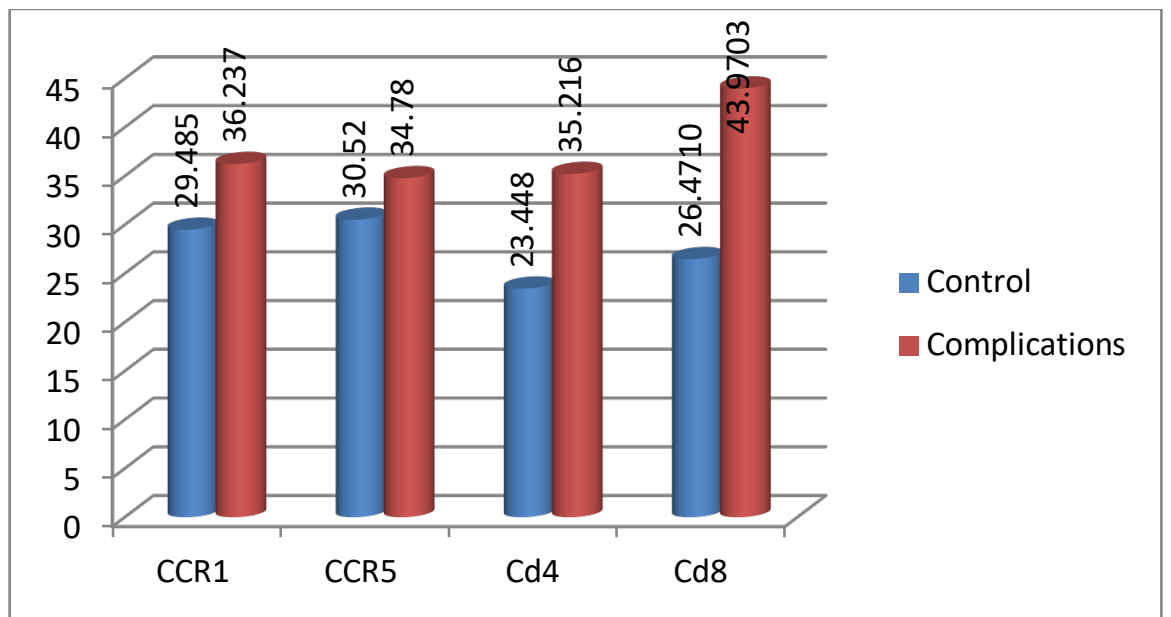

Figure 5: Levels of CCR1, CCR5, CD4 and CD8 in control and CLD

CCR1 level was slightly increased $(\mathrm{P}>0.05)$ in active schistosomiasis group than $2^{\text {nd }}$ day in treated group $(\mathrm{M} \pm \mathrm{SD}$ $=25.27 \pm 7.26$ and 20.06 \pm 5.66 , respectively). But CCR5 level was significantly increased $(\mathrm{P} \leq 0.05)$ in active schistosomiasis group than its level in $2^{\text {nd }}$ day in treated group $(\mathrm{M} \pm \mathrm{SD}=23.43 \pm 8.04$ and $14.90 \pm 4.56$, respectively) as shown in figure (6).

CCR1 level was significantly increased $(\mathrm{P} \leq 0.05)$ in active schistosomiasis group than $4^{\text {th }}$ day in treated group $(\mathrm{M} \pm \mathrm{SD}=$ $25.27 \pm 7.26$ and $15.98 \pm 5.86$, respectively). Also, CCR5 level was significantly increased $(\mathrm{P} \leq 0.05)$ in active schistosomiasis group than $4^{\text {th }}$ day in treated group $(\mathrm{M} \pm \mathrm{SD}=23.43 \pm 8.04$ and $14.21 \pm 6.81$, respectively) as shown in figure (6).

CCR1 level was significantly increased $(\mathrm{P} \leq 0.05)$ in active schistosomiasis group than $6^{\text {th }}$ day in treated group $(\mathrm{M} \pm \mathrm{SD}=$ $25.27 \pm 7.26$ and $16.89 \pm 4.70$, respectively). But CCR5 level was significantly increased $(\mathrm{P} \leq 0.05)$ in in active schistosomiasis group than $6^{\text {th }}$ day in treated group $(\mathrm{M} \pm \mathrm{SD}=23.43 \pm 8.04$ and 9.33 \pm 5.40 , respectively) as shown in figure (6). 
Samir A. El-Masry et al.

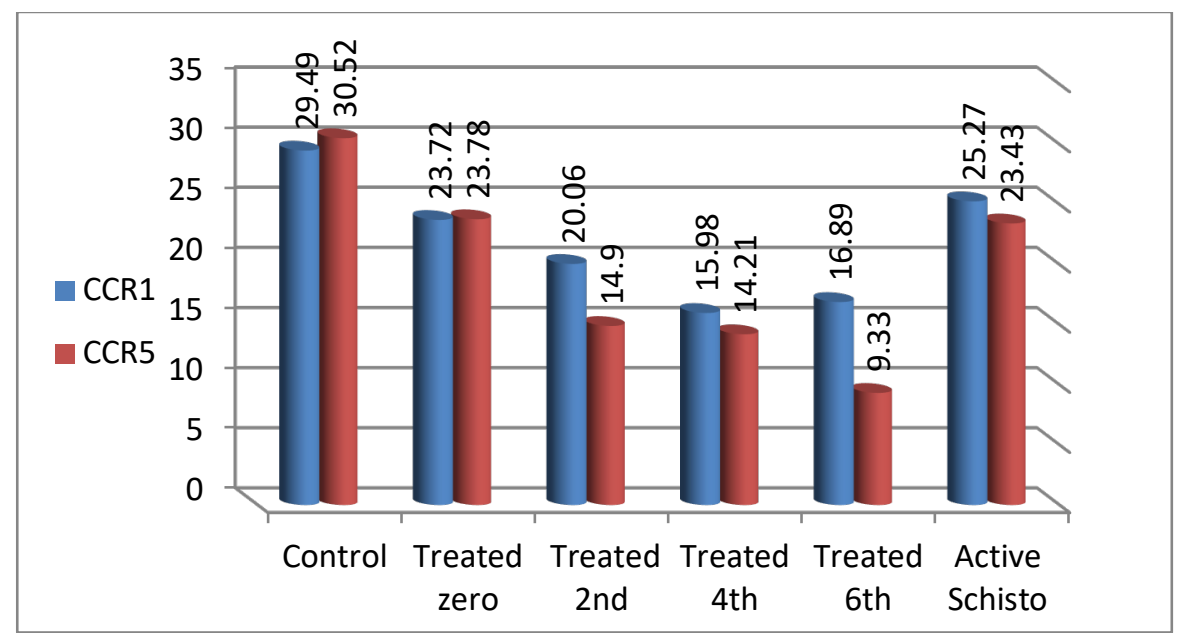

Figure 6: Levels of CCR1 and CCR5 in group control, treated samples and active schistosomiais.

\section{DISCUSSION}

Chemokine receptors (CCRs) are important co-stimulatory molecules found on many blood cells and associated with various diseases. The expression and function of CCRs on mast cells has been quite controversial (27) . Chemokine receptors as such represent attractive therapeutic targets. However, structural and functional studies have been hampered by many difficulties associated with expression and purification ${ }^{(\mathbf{2 8})}$.

The role of chemokines and their receptors in mediating granulomatous inflammation induced by $S$. mansoni egg antigens presented in particulate manner have been studied in detail. In humans, levels of CCL3 in plasma associate with disease severity and may be useful for diagnostic purposes. In contrast, absence of CCR 5 is associated with enhanced lethality, granuloma size and fibrosis ${ }^{(29)}$.

In our study, we found that the level of CCR1 was significantly increased $(p=0.014)$ in CLD group than that in healthy control group. These results are in agreement with many recent previous findings $(\mathbf{1 1}, \mathbf{1 2}, \mathbf{1 9}, \mathbf{1 4 )}$. But the increment of CCR5 had no marked difference $(p=0.099)$, these results didn't agree with ${ }^{(29)}$ which 


\section{Expression of CCR1 \& CCR5 in shistosomiasts patients}

demonstrated that there was a decrease in CCR5 levels in CLD patients compared with healthy individuals. This is due to CCL5/CCR5 remains the sole chemokine/chemokine receptor pair to have a role at negatively modulating granulomatous response and to be associated with less severe disease.

CCR1 and CCR5 have all been implicated in hepatic inflammation. CCR5 expressing CD8 $\mathrm{T}$ cells are enriched in the inflamed human liver. In the current study, we found that CD8 was significant increase $(p=0.011)$ in CLD group than in healthy control group. These results are in agreement with many previous findings ${ }^{(30}$, 31). Also, we found that CD4 was significant increase $(p=0.028)$ in CLD group than in healthy control group. These results are in agreement with recent previous finding ${ }^{(32)}$. These results can be interpreted by; chemokines have the ability to induce migration of specific subsets of leucocytes, both effectors and regulators and are critical regulators of immunity and inflammation in human liver diseases ${ }^{(33)}$.

In the present study, the data revealed that apoptosis level in untreated group was slightly higher than that in treated group after two days in cultured medium $(\mathrm{M} \pm \mathrm{SD}=32.17 \pm 8.68$, $23.90 \pm 18.59$, respectively). While the immunological role of SEA was appear after the $4^{\text {th }}$ day of culture by decreasing the apoptosis level in untreated group and increasing in treated group $(\mathrm{M} \pm$ $\mathrm{SD}=19.28 \pm 22.76,38.08 \pm 22.41$, respectively). These results are in agreement with the study of Steven et al., $2001{ }^{(34)}$ which reported that SEA stimulus induces almost simultaneous T-cell activation and activation induced cell death.

The endemic cases of patient are under different exposure conditions to the infection than the experimental animals. It was shown that cells from these individuals spontaneously enter $\mathrm{S}$ phase of the cell cycle upon culture, but instead of completing mitosis, these cells tend to undergo apoptosis ${ }^{(35)}$. However, the precise mechanisms involved in the modulation of lymphocyte response to SEA are not yet clear and more detailed analysis is still needed. Campi-Azevedo et al., $2007^{(36)}$, observed that the cells were capable of progressing through the cell cycle. Stimulation of PBMCs from infected patients 
with SEA resulted in a lower frequency of $\mathrm{T}$ cells in $\mathrm{S}$ phase when compared with the non-infected group. But our data revealed that $\mathrm{S}$ phase in untreated individuals have gradually decrease from zero to $2^{\text {nd }}, 4^{\text {th }}$ and $6^{\text {th }}$ day $(\mathrm{M} \pm \mathrm{SD}=6.56 \pm 2.41,4.92 \pm 8.01,2.64 \pm 3.82$ and $2.83 \pm 3.71$, respectively), was in lower frequency of PBMCs when compared with the treated group, $\mathrm{S}$ phase values have marked decrease from zero to $2^{\text {nd }}, 4^{\text {th }}$ and $6^{\text {th }}$ days $(\mathrm{M} \pm \mathrm{SD}=12.03 \pm 10.28$, $1.24 \pm 2.64,1.16 \pm 2.31$ and $2.82 \pm 4.75$, respectively), these results didn't agree with ${ }^{(36)}$. But these decrements are in agreement with ${ }^{(37)}$ that have studied the effect of curcumin on the proliferation and apoptosis of hepatic stellate cells (HSC) and indicated that Curcumin inhibits HSC proliferation in the $\mathrm{S}$ phase and induces apoptosis, this related to the activation of peroxisome proliferator $^{(38)}$.

Some experiments were demonstrated a down regulation of immune responses which in vitro involves a reduction of proliferative response to parasite antigens and decrease in the granuloma formation index during the monocyte differentiation pathway. CCR1 levels had no marked decreased ( $\mathrm{p}=0.283,0.570,0.683$ and 0.933 , respectively) in treated group than that in untreated group. Also, CCR5 levels had no marked decreased ( $\mathrm{p}=0.368,0.461,0.109$ and 0.570 , respectively) in treated group than that in untreated group. These results are in agreement with previous finding ${ }^{(39)}$ which demonstrated that one probable mechanism involved in these phenomena may be the down regulation of surface expression of HLA-DR and CD54 adhesion costimulatory molecules.

Active schistosomiasis mansoni patients showed increase in CD8 and decrease in CD4. We found that CD4 slightly decrease $(p=0.368)$ in active schistosomiasis mansoni when compared with healthy control, while CD8 increase $(p=0.875)$ in active schistosomiasis mansoni group when compared with healthy control group. These results are in matching with the previous research of many ancient finding ${ }^{(32)}$.

Activation of CCR1 appears to drive leukocyte recruitment, granuloma formation and collagen deposition $(\mathbf{4 0 , 4 1 )}$. In contrast, CCL5 acting on CCR5 has regulatory effects and control disease severity via control of inflammation and collagen deposition ${ }^{(29)}$. 
However, other mediators are to be disregarded, but that the two chemokine receptors are important players in this multi-faceted inflammatory context. In the current study CCR1 and CCR5 levels had no marked increase ( $\mathrm{p}=0.313$ and 0.093 , respectively) in healthy control group compared with active schistosomiasis mansoni patients. These results are in agreement with previous finding $(\mathbf{4 0 , 4 1 )}$.

In conclusion, the down regulation of CCR1 and CCR5 in vitro and in vivo studies may illustrate the immunological role of SEA in granuloma formation and collagen deposition in active schistosomiasis patients.

\section{REFEREN}

1. Savioli, L., Albonico, M., Engels, D. and Montresor, A. Progress in the prevention and control of schistosomiasis and soil-transmitted helminthiasis. Parasitol Int; 53(2):103113(2004).

2. McManus D.P. and Loukas A. Current status of vaccines for schistosomiasis. Clin Microbiol Rev; 21(1):225-242(2008).

3. Siddiqui, A.A., Ahmad, G., Damian, R.T. and Kennedy, R.C. Experimental vaccines in animal models for schistosomiasis. Parasitol Res; 102(5):825-833(2008).

4. Pearce, E.J. and MacDonald, A.S. The immunobiology of schistosomiasis. Nat. Rev. Immunol.; 2(7): 499-511(2002).

5. Gause, W.C., Urban, J.F. and Stadecker, M.J. The immune response to parasitic helminths: insights from murine models. Trends Immunol.; 24(5), 269-277(2003).

6. Domingues, A.L.C., Pereira, L.M.M.B. and Barreto, V.S.T. Esquistossomose In: Federaãćo Brasileira de Gastroenterologia. Condutas em Gastroenterologia. São Paulo: Revinter; p. 462-474(2004).

7. Shona, W., Frances, M.J., Joseph, K.M., Gachuhi, K., Mark, B.H. Curtis, K., Birgitte, J.V., John, H.O., Eric, M. and David W. Hepatosplenomegaly Is Associated with Low 
Regulatory and Th2 Responses to Schistosome Antigens in Childhood Schistosomiasis and Malaria Coinfection \{triangledown\}: Infect Immun.;76(5):2212-2218(2008).

8. Boros, D.L., and Warren, K.S. Delayed hypersensitivity-type granuloma formation and dermal reaction induced and elicited by a soluble factor isolated from Schistosoma mansoni eggs. J. Exp. Med.; 132(3): 488-507(1970).

9. Mathew, R.C. and Boros, D.L. Anti-L3T4 antibody treatment suppresses hepatic granuloma formation and abrogates antigen-induced interleukin- 2 production in Schistosoma mansoni infection. Infect. Immun.; 54(3): 820-826(1986).

10. Qiu, B., Frait, K.A., Reich, F., Komuniecki, E. and Chensue, S.W. Chemokine expression dynamics in mycobacterial (type 1) and schistosomal (type 2) antigen-elicited granulomatous inflammation. Am J Pathol; 158: 1503-1515(2001).

11. Falcao, P.L., Correa-Oliveira, R., Fraga, L.A.O., Talvani, A., Proudfoot, A.E., Wells, T.N.C., Williams, T.J., Jose, P.J. and Teixeira, M.M. Plasma concentrations and role of macrophage inflammatory protein-1 (MIP-1/CCL3) during chronic Schistosoma mansoni infection in humans. J. Infect. Dis.; 186: 1696-1700(2002).

12. Souza, A.L., Roff ${ }^{\wedge}$, E., Pinho, V., Souza, D.G., Silva, A.F., Russo, R.C., Guabiraba, R., Pereira, C.A., Carvalho, F.M., Barsante, M.M., Correa-Oliveira, R., Fraga, L.A., NegraoCorrea, D. and Teixeira, M.M. Potential role of the chemokine macrophage inflammatory protein lalpha in human and experimental schistosomiasis. Infect. Immun.; 73(4): 2515-2523(2005).

13. Menten P., Wuyts A. and Van Dame J. Macrophage inflammatory protein-1. Cytokine Growth Factor Rev.; 13(6): 455-481(2002).

14. Souza, A.L., Sousa-Pereira, S.R., Teixeira, M.M., Lambertucci, J.R. and Teixeira, A.L. The role of chemokines in 
Schistosoma mansoni infection: insights from human disease and murine models. Mem. Inst. Oswaldo Cruz 101 Suppl.; 1: 333-338(2006).

15. Yurchenko, E., Tritt, M., Hay, V., Shevach, E.M., Belkaid, Y. and Piccirillo, C.A. CCR5-dependent homing of naturally occurring $\mathrm{CD} 4+$ regulatory $\mathrm{T}$ cells to sites of Leishmania major infection favors pathogen persistence. J. Exp. Med.; 203(11): 2451-2460(2006).

16. Gao, J.L., Wynn, T.A., Chang, Y., Lee, E.J., Broxmeyer, H.E., Cooper, S., Tiffany, H.L., Wespahl, H., Kwon-Chung, J. and Murphy, P.M. Impaired host defense, hematopoiesis, granulomatous inflammation, and type 1-type 2, cytokine balance in mice lacking $\mathrm{CC}$ chemokine receptor 1. J. Exp. Med.; 185(11): 1959-1968(1997).

17. Chensue, S.W., Warmington, K.S., Allenspach, E.J., Lu, B., Gerard, C., Kunkel, S.L. and Lukacs, N.W. Differential expression and cross-regulatory function of RANTES during mycobacterial (type1) and schistosomal (type 2) antigenelicited granulomatous inflammation. J. Immunol.; 163 ; 165-173 (1999).

18. Booth, M., Mwatha, J.K., Joseph, S., Jones, F.M., Kadzo, H., Ireri, E., Kazibwe, F., Kemijumbi, J., Kariuki, C., Kimani, G., Ouma, J.H., Kabatereine, N.B., Vennervald, B.J., and Dunne, D.W. Periportal fibrosis in human Schistosoma mansoni infection is associated with low IL-10, low IFNgamma, high TNF-alpha, or low RANTES, depending on age and gender. J. Immunol;; 172(2): 1295-1303(2004).

19. Sousa-Pereira, S., Teixeira, A.L., Silva, L.C., Souza, A.L., Antunes, C.M., Teixeira, M.M. and Lambertucci, J.R. Serum and cerebral spinal fluid levels of chemokines and Th2 cytokines in Schistosoma mansoni myeloradiculopathy. Parasite Immunol.; 28(9): 473-478(2006). 
20. Harris, R. and Ukaejiofo, E.O. Tissue typing using a routine onestep lymphocyte separation procedure. Brit.J.Haemat.; 18(2): 229-235(1970).

21. Ting, A. and Morris, P.J. A technique for lymphocyte preparation from stored heparinized blood. Vox Sang.; 20(6): 561-563(1971).

22. Braylan, R.C., Benson, N.A., Nourse, V., and Kruth, H.S. Correlated analysis of cellular DNA, membrane antigens, and light scatter of human lymphoid cells. Cytometry, 2(5):337343 (1982).

23. Orfao, A., Ciudad, J., Gonzalez, M., Lopez, A., del Mar Abad, M., Paz Bouza, J.I., Cruz, J.J., Gomez Alonso, A. and San Miguel, J.F. Flow cytometry in the diagnosis of cancer. Scand J Clin Lab Invest.; 221:145-152(1995).

24. Tribukait, B. Flow cytometry in surgical pathology and cytology of tumors of the genito-urinary tract. Adv. Clin. Cytol.; 2: 163-189(1984).

25. Ormerod, A.D., Weller, R., Copeland, P., Benjamin, N., Ralston, S.H., Grabowksi, P. and Herriot, R., Detection of nitric oxide and nitric oxide synthases in psoriasis. Arch Dermatol Res; 290(1-2): 3-8(1998).

26. Cohen, J.J. and Al-Rubeai, M. "Apoptosis-targeted therapies: the next big thing in biotechnology?" Trends Biotechnol; 13(8): 281-283(1995).

27. Nimita, H.F., Cho, C.A., Sandeep, K.R., Ricardo, M.R. and Santa Jeremy, O. CCR1 expression and signal transduction by murine BMMC results in secretion of TNF-a, TGFb-1 and IL-6. Int Immunol.;21(8):991-1001. (2009).

28. McCusker, E.C., Bane, S.E., O'Malley, M.A. and Robinson, A.S. Heterologous GPCR expression: a bottleneck to obtaining crystal structures, Biotechnol. Prog.; 23(3): 540547(2007). 
29. Patricia, R.S.S., Adriano, L.S.S., Deborah, N.C., Antonio, L.T. and Mauro, M.T. The role of chemokines in controlling granulomatous inflammation in Schistosoma mansoni infection, Acta Trop.;108(2-3):135-138(2008).

30. Shields, P.L., Morland, C.M., Salmon, M., Qin, S., Hubscher, S.G. and Adams, D.H. Chemokine and chemokine receptor interactions provide a mechanism for selective $\mathrm{T}$ cell recruitment to specific liver compartments within hepatitis Cinfected liver. J Immunol;163(11):6236-6243(1999).

31. Boisvert, J., Kunkel, E.J., Campbell, J.J., Keeffe, E.B., Butcher, E.C., and Greenberg, H.B. Liver-infiltrating lymphocytes in end-stage hepatitis $\mathrm{C}$ virus: subsets, activation status, and chemokine receptor phenotypes. J Hepatol; 38 (1):67-75(2003).

32. Shahat, S.A., El-Dhshan, M.A., Aissa, S.S., Dorra, A. and Metwally, K.M. Flowcytometric analysis of T-lymphocytes and serum tumour necrosis factor alpha (TNF-alpha) levels in schistosoma mansoni patients. J Egypt Soc Parasitol.; 37 (3): 1065-1074(2007).

33. Oo, Y.H., Shetty, S. and Adams, D.H.The role of chemokines in the recruitment of lymphocytes to the liver. Dig Dis.; 28(1):31-44 (2010).

34. Steven, K.L., Stephen, P.L. and Dov, L.B. Soluble Egg AntigenStimulated T Helper Lymphocyte Apoptosis and Evidence for Cell Death Mediated by FasL1 T and B Cells during Murine Schistosoma mansoni Infection. Infection and Immunity; 271280(2001).

35. Azuma, A., Matsuo, A., Suzuki, T., Kurosawa, T., Zhang, X. and Aida, Y. Human immunodeficiency virus type $1 \mathrm{Vpr}$ induces cell cycle arrest at the G (1) phase and apoptosis via disruption of mitochondrial function in rodent cells, Microbes Infect.; 8(3): 670-679(2006). 
36. Campi-Azevedo, A.C., Gazzinelli, G., Bottazzi, M.E., TeixeiraCarvalho, A., Corrêa-Oliveira, R. and Caldas, I.R. In vitro cultured peripheral blood mononuclear cells from patients with chronic schistosomiasis mansoni show immunomodulation of cyclin D1, 2, 3 in the presence of soluble egg antigens. Microbes Infect.; 9(12-13):14931499(2007).

37. Shu, J.C., He, Y.J., Lv, X., Zhao, J.R., Zhao, J., Shen, Y., Ye, G.R. and Wang, L.X. Effect of curcumin on the proliferation and apoptosis of hepatic stellate cells. Braz J Med Biol Res.; 42(12):1173-8 (2009).

38. Xu, J., Fu, Y. and Chen, A. Activation of peroxisome proliferator-activated receptor-gamma contributes to the inhibitory effects of curcumin on rat hepatic stellate cell growth. Am J Physiol Gastrointest Liver Physiol; 285: G20G30 (2003).

39. Silva-Teixeira, D.N., Doughty, B.L. and Goes, A.M. Human Schistosomiasis: Modulation of In Vitro Granulomatous Hypersensitivity and Lymphocyte Proliferative Response by Macrophages Undergoing Differentiation. Scand J Immunol.; 44(5):522-529(1996).

40. Warmington, K.S., Boring, L., Ruth, J.H., Sonstein, J., Hogaboam, C.M., Curtis, J.L., Kunkel, S.L., Charo, I.R. and Chensue, S.W. Effect of $\mathrm{C}-\mathrm{C}$ chemokine receptor 2 (CCR2) knockout on type-2 (schistosomal antigen elicited) pulmonary granuloma formation: analysis of cellular recruitment and cytokine responses. Am. J. Pathol.; 154(5): 1407-1416(1999).

41. Jakubzick, C., Wen, H., Matsukawa, A., Keller, M., Kunkel, S.L. and Hogaboam, C.M. Role of CCR4 ligands CCL17 and CCL22 during Schistosoma mansoni egg-induced pulmonary granuloma formation in mice. Am. J. Pathol.; 165(4): 12111221(2004). 